American Journal of Biochemistry and Biotechnology 5 (1): 35-39, 2009

ISSN 1553-3468

(C) 2009 Science Publications

\title{
Cadmium Induced Changes in Metabolic Function of Mitochondrial Isolated from Potato Tissue (Solanum tuberosum L.)
}

\author{
${ }^{1}$ Chagra Ali, ${ }^{1}$ Djebar Mohammed Réda, ${ }^{2}$ Rouabhi Rachid and ${ }^{1}$ Berrebbah Houria \\ ${ }^{1}$ Laboratory of Cellular Toxicology, Annaba University, 23000, Algeria \\ ${ }^{2}$ Nature and Life Sciences Institute, Department of Biology, Tebessa University, 12000, Algeria
}

\begin{abstract}
Problem statement: Cadmium is highly toxic at low concentrations, but the mechanism of its toxicity is still not understood particularly at the cellular and subcellular level. Approach: In this study we examined the effects of cadmium on the oxidophosphorylation properties of mitochondria isolated from potatoes. Results: Cadmium strongly disturbed the respiratory metabolism of mitochondria isolated especially in the transfer of electrons by cyanide pathway. Meanwhile, cadmium altered the composition of lipid fatty acids polar while inhibiting catalase activity, a key enzyme in the detoxification (antioxidant) process. In addition, cadmium caused an increase in mitochondrial volume associated with strong inhibition of ATPase activity, which could be explained by a transport of the potassium ion stimulation at the origin of the massive influx of $\mathrm{H}^{+}$by antiport through the $\mathrm{K}^{+} / \mathrm{H}^{+}$ leading to a decoupling (cut) of mitochondrial oxidative phosphorylation. The swelling of mitochondria was accompanied by the rupture of the mitochondrial outer membrane and thus the release of Cytochrome C, which appears to be the initial phase of apoptosis. Conclusion: Following this study, it appeared that cadmium generates in potato the isolated mitochondria a concentrationdependent oxidative stress.
\end{abstract}

Key words: Cadmium, mitochondria, catalase, ATPase, swelling, lipids

\section{INTRODUCTION}

Heavy metals are the major pollutants of the environment, especially cadmium, which is highly toxic in trace amounts for humans, animals and plants. The various industrial processes and the massive use of fertilizers are the main sources of pollution by cadmium; it once in the soil is easily transferred into the food chain through plants ${ }^{[26]}$. Studies conducted on different plant species showed that cadmium is very phytotoxic, it inhibits the growth of plants and even cause death of plants. However, the mechanisms involved in the toxicity of cadmium remain not clear. Some authors show that cadmium is causing alterations in cell membrane functions by changing the composition of the lipid membranes ${ }^{[13]}$. Other studies showed that cadmium is responsible for the oxidation of proteins ${ }^{[16]}$. Cadmium also affects the enzyme activities involved in the detoxification of $\mathrm{H}_{2} \mathrm{O}_{2}$ and $\mathrm{O}_{2}$ preventing the formation of free radicals $(\mathrm{OH})^{[11]}$. In animals, it was shown that cadmium induced changes in the antioxidant status by increasing the production of superoxide radical, lipid peroxydation or by reducing the enzymatic and non-enzymatic antioxidants ${ }^{[23]}$. Meanwhile, little information exists on the effect of cadmium on plants. In Phaseolus vulgaris, for example, the toxicity of cadmium is translated by a lipid peroxidation followed by a deterioration of antioxidant systems $^{[8,18-22]}$ In this study, the direct effect of low concentrations of cadmium on respiratory metabolism of mitochondria isolated from potatoes through different enzyme and biochemical parameters was studied in order to seek the involvement of cadmium in the induction of oxidative stress in mitochondria.

\section{MATERIALS AND METHODS}

Preparation of purified mitochondria potatoes and quantification of proteins: The mitochondria of Potato (Solanum tuberosum L.) are differential centrifuged in a medium containing $0.3 \mathrm{M}$ mannitol, MOPS (sulfonic morpholinopropan) $5 \mathrm{mM}$ (pH7.2); Cysteine $3 \mathrm{mM}$, PVP (Polyvinylpyrolidone) $4 \mathrm{~g} \mathrm{~L}^{-1}$; BSA (Beef Serum Albumin) $1 \mathrm{~g} \mathrm{~L}^{-1}$. The mitochondria are then purified on a discontinuous gradient of Percoll $(15,25,35$ and $70 \%$ ) containing $0.3 \mathrm{M}$ of mannitol, $5 \mathrm{mM}$ of MOPS $(\mathrm{pH} 7.2)$. Organelles are collected at the interface of Percoll 25/35\% and then washed and re-suspended in the compound of measurement composed of mannitol

Corresponding Author: Chagra Ali, Laboratory of Cellular Toxicology, Annaba University, 23000, Algeria 
0, $3 \mathrm{M}$, MOPS $5 \mathrm{mM}(\mathrm{pH} 7.2)^{[5]}$. Proteins level is determined by the method of ${ }^{[2]}$.

Treatment of mitochondria by cadmium: The treatment of mitochondria isolated from potato is done by submitting the mitochondrial suspensions at different concentrations of Cadmium $(0,4,8,12,16$ and $20 \mu \mathrm{M}$ ) for $5 \mathrm{~min}$ and $25^{\circ} \mathrm{C}$.

Mitochondrial activities: Determinations of oxidation speeds in state of phosphorynat $\left(\operatorname{Vox}_{3}\right)$ and nonphosphorylation $\left(\operatorname{Vox}_{4}\right)$ are performed at $25^{\circ} \mathrm{C}$ using Clark electrode oxygen ${ }^{[6]}$. The reaction mixture consists of $0.3 \mathrm{M}$ of mannitol, $10 \mathrm{mM}$ of phosphate buffer $\left(\mathrm{KH}_{2} \mathrm{PO}_{4} / \mathrm{K}_{2} \mathrm{HPO}_{4}\right)$ and $(\mathrm{pH} 7.2) ; 5 \mathrm{mM}$ of $\mathrm{MgCl}_{2}$, $10 \mathrm{mM}$ of $\mathrm{KCl}$ and $1 \mathrm{~g} \mathrm{~L}^{-1}$ of BSA. The evaluation of the effects of cadmium on the alternative respiratory way of mitochondria isolated from potatoes is done in the presence of $1 \mathrm{mM}$ of $\mathrm{KCN}$.

ATPase activity: The ATPase activity is performed using Bomsel ${ }^{[1]}$ method, based on the determination of ATP by bioluminescence through the reaction catalyzed by the couple luciferin-luciferase ${ }^{[14]}$.

Enzyme activity, catalase: Catalase activity (EC 1.11.1.6.) is measured using an oxygen electrode using method of Van Ginkel and Brown ${ }^{[25]}$ in a medium containing $0.3 \mathrm{M}$ of mannitol, $5 \mathrm{mM}$ of MOPS with (pH7.2) and 200-300 $\mu \mathrm{g}$ of membrane proteins. The environment is first swept by nitrogen to reduce the concentration of $\mathrm{O}_{2}$. The reaction is triggered by the addition of $1 \mathrm{mM}$ of $\mathrm{H}_{2} \mathrm{O}_{2}$ and oxygen release is measured through time.

Measurement of swelling of mitochondria: Measurements of swelling (bulge) of mitochondria are performed at $25^{\circ} \mathrm{C}$ with a spectrophotometer (Jenway, model UV6300) following changes of mitochondrial suspensions absorption at $\lambda=520 \mathrm{~nm}$. The suspension middle contains $100 \mathrm{mM}$ of $\mathrm{KCl}$. The reaction is triggered by the addition of mitochondria (1-1.5 mg of protein for a final volume of $3 \mathrm{~mL}$ ).

Lipid analysis: The fatty acids of polar lipids are analyzed under methyl esters form ${ }^{[7]}$. The methyl esters were separated by chromatography in (Girdel, S30) phase.

\section{RESULTS}

Effects of cadmium on potatoes mitochondrial oxidative properties: The effects of different concentrations of cadmium on oxidative properties of mitochondria isolated from potatoes are showed on the Table 1. During treatment by cadmium, oxidation speeds in state 3 and 4 decreases from the lowest concentration. In $12 \mu \mathrm{M}$ of cadmium oxidation speed is reduced approximately $10 \%$, beyond this concentration oxidation speed is completely inhibited. Meanwhile, treatment by cadmium does not appear to affect significantly the speed of oxidation in state 4 where there is only a $20 \%$ in the highest concentration of cadmium $(12 \mu \mathrm{M})$. Respiratory Controls obtained in function of concentrations of cadmium showed a significant decline $(>50 \%)$ especially in the $12 \mu \mathrm{M}$ concentration. The same for ADP/O because of a similar decline was recorded after treatment with the same concentration.

Effects of cadmium on the functioning of the alternative respiratory pathway: Figure 1 shows the effects of different concentrations of cadmium on the oxidation speed of state 4 in the presence of $1 \mathrm{mM}$ of $\mathrm{KCN}$.

Table 1: Effect of cadmium on the oxidative activities of Potato mitochondria. Mitochondrial protein concentration: $0.1 \mathrm{mg} \mathrm{mL}^{-1}$. The concentration of Succinate is $2 \mathrm{mM}$ Oxidation speed (n moL $\mathrm{min}^{-1} \mathrm{mg}^{-1}$ prot.)

\begin{tabular}{lllll}
$\mathrm{Cd}(\mu \mathrm{M})$ & State 3 & State 4 & $\mathrm{RC}$ & ADP/O \\
\hline 0 & 180 & 49 & 3,7 & 1,30 \\
4 & 159 & 46 & 3,4 & 0,90 \\
8 & 84 & 44 & 1,9 & 0,80 \\
12 & 69 & 40 & 1,7 & 0,70 \\
16 & $\mathrm{Nd}$ & $\mathrm{Nd}$ & $\mathrm{Nd}$ & $\mathrm{Nd}$ \\
20 & $\mathrm{Nd}$ & $\mathrm{Nd}$ & $\mathrm{Nd}$ & $\mathrm{Nd}$ \\
\hline \multicolumn{2}{l}{ Nd: Not Determined; RC: Respiratory Control }
\end{tabular}

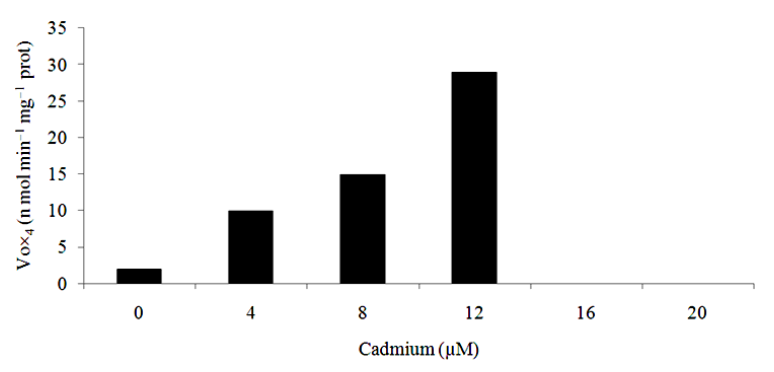

Fig. 1: Effects of cadmium on the oxidative activities of mitochondrial Potato (oxidation speeds in non-phosphorylant 'Vox 4 ' state "alternative pathway of electron transfer). Mitochondrial protein concentration: $0.1 \mathrm{mg} \mathrm{mL}^{-1}$, the concentration of $\mathrm{KCN}$ is $1 \mathrm{mM}$ 
Am. J. Biochem. \& Biotech., 5 (1): 35-39, 2009

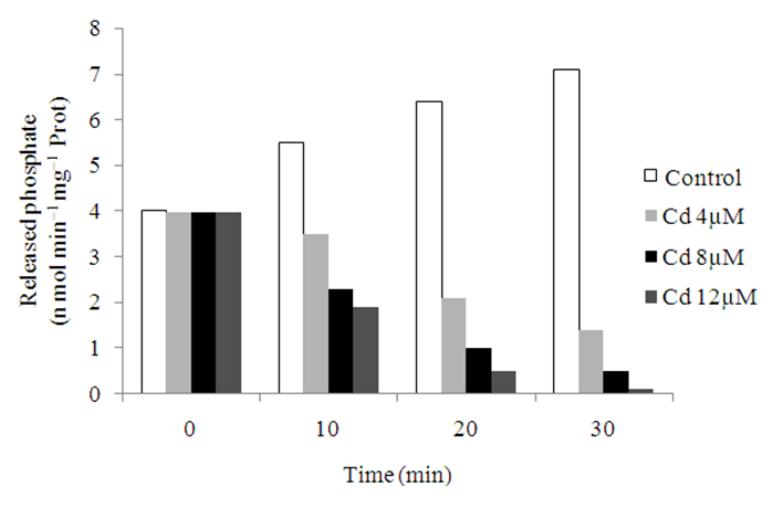

Fig. 2: Effects of cadmium on the ATPase activity of potato purified mitochondria. The ATP concentration was $2 \mathrm{mM}$

It finds that with increasing of the cadmium concentration in the presence of $\mathrm{KCN}$ the rate of oxidation speed in state 4 is stimulated to reach in $12 \mu \mathrm{M}$ cadmium 15 times higher than in controls mitochondria. This stimulation of $\operatorname{Vox}_{4}$ reflected an activation of more and more important of the transfer pathway of electrons insensitive to cyanide by cadmium.

Effect of cadmium on the ATPase activity of mitochondria isolated from potatoes: The results about the effects of different concentrations of cadmium on the ATPase activity of isolated mitochondria are shown in Fig. 2

Figure 2 shows that the controls mitochondria have a high ATPase activity. Treatment with cadmium tends to reduce significantly this activity, so in $4 \mu \mathrm{M}$ there is nearly $50 \%$ of inhibition. Increasing concentrations of cadmium reduce the speed of hydrolysis of ATP especially after $30 \mathrm{~min}$ of incubation. In $12 \mu \mathrm{M}$ of cadmium hydrolysis speeds of ATP are practically nil.

Effects of cadmium on changes in the volume of mitochondria isolated mitochondrial potatoes: The changes in absorbance of mitochondrial suspensions at $520 \mathrm{~nm}$ associated with fluctuations in the volume of these organelles are shown in Fig. 3.

The swelling of mitochondria under the effect of treatment by cadmium is accompanied with significant change of the absorbance. A significant decrease of absorbance is observed during the first $5 \mathrm{~min}$ and then it slows down to reach a plateau after $20 \mathrm{~min}$. It is important to note that treatment with 8 and $12 \mu \mathrm{M}$ of cadmium causes sizable swelling of treated mitochondria about (70\%).

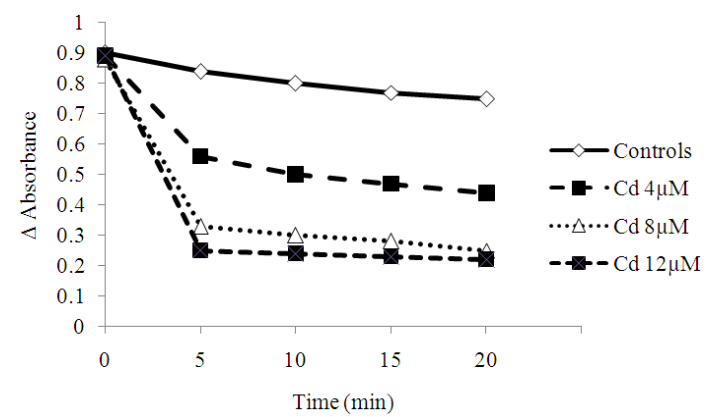

Fig. 3: Effects of cadmium on the volume of mitochondria isolated from potato

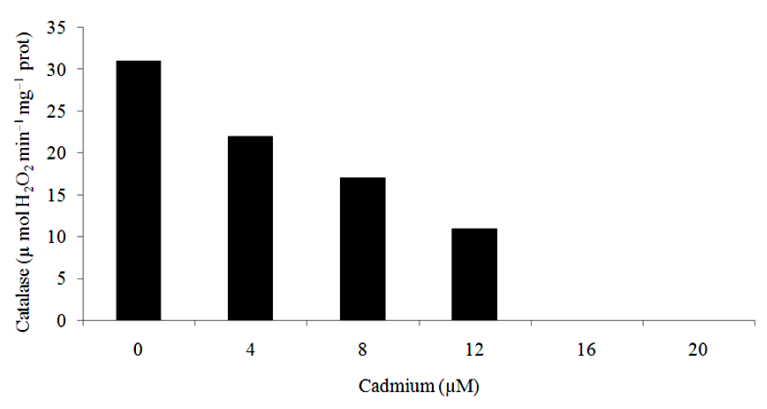

Fig. 4: Effects of cadmium on the catalase enzyme activity of mitochondria of potatoes. Mitochondrial protein concentration: $0.1 \mathrm{mg} \mathrm{mL}^{-1}$

Table 2: Effects of different concentrations of cadmium on the content of fatty acids in polar lipids

Relative contents of fatty acid (\%)

\begin{tabular}{llll}
$\mathrm{Cd}(\mu \mathrm{M})$ & Palmitic acid $\left(\mathrm{C}_{16: 0}\right)$ & Linoleic acid $\left(\mathrm{C}_{18: 2}\right)$ & Linolenic acid $\left(\mathrm{C}_{18: 3}\right)$ \\
\hline 0 & 15 & 10 & 36 \\
4 & 19 & 07 & 33 \\
8 & 24 & 03 & 17 \\
12 & 27 & 01 & 14 \\
16 & $\mathrm{Nd}$ & $\mathrm{Nd}$ & $\mathrm{Nd}$ \\
20 & $\mathrm{Nd}$ & $\mathrm{Nd}$ & $\mathrm{Nd}$ \\
\hline
\end{tabular}

Effects of cadmium on the polar lipids of fatty acid content of potatoes isolated mitochondria: The results of the effects of different concentrations of cadmium on the content of fatty acids in polar lipids are shows in Table 2. The Table 2 shows that the levels of fatty acids in polar lipids of mitochondria isolated from potatoes are high in linolenic acid (C18: 3), approximately 60 palmitic acid (C16: 0 ) and $75 \%$ linoleic acid (C18: 2). Treatment with different concentrations of cadmium increases the levels of palmitic acid nearly $50 \%$ at the concentration of cadmium $12 \mu \mathrm{M}$. Contrarily, treatment with cadmium causes rather a reduction in the relative content of 
linoleic acid and linolenic almost 90 and $70 \%$ respectively.

Effects of cadmium on antioxidant enzyme activity, catalase: The effects of different concentrations of cadmium on changes in the antioxidant activity Catalase are shown on Fig. 3 and 4

We note that the high Catalase activity in mitochondria controls tended to decrease depending on the concentrations of cadmium. At $8 \mu \mathrm{M}$ of cadmium this activity is reduced about 50\% and it canceled beyond $12 \mu \mathrm{M}$ of cadmium. This result shows clearly that cadmium significantly reduces Catalase activity, a key enzyme whose primary role is the detoxification of cells. The reduction of Catalase activity in mitochondria isolated from Potato exposes these organelles to the adverse effects of cadmium by increasing the production of Reactive Oxygen Species (ROS).

\section{DISCUSSION}

The oxidative properties of mitochondrial Potato treated by cadmium are heavily affected, particularly oxidation speeds in phosphorylant state 3 and non phosphorylant state 4, the Respiratory Control (RC) and the ADP/O. Its effects showed that cadmium acts at the level of oxidative phosphorylation particularly at the pathway of transfer of electrons particularly insensitive towards cyanide ${ }^{[4,16]}$.

Our results also show that cadmium significantly inhibits the ATPase activity through the reduction of the ATP hydrolysis. This result is in line with the observations of Claes ${ }^{[3]}$, on mitochondria isolated from kidney cell lines and where the authors show that in addition to the inhibition of ATPase activity, inhibition of the reductases activities associated with electrons transfer Chain is observed.

Meanwhile, the values of mitochondrial volume ( $\Delta$ Absorbance) of mammals ${ }^{[15]}$, the data obtained in our study on mitochondria isolated from Potato suggest that changes in volume of these organelles are much higher. This result confirms those obtained by ${ }^{[9,10]}$. When the mitochondrial swelling is the cause of the release of mitochondrial Cytochrome $\mathrm{C}$ and hence the induction of apoptosis ${ }^{[12,24]}$.

The obtained results in our study on changes in the composition of lipids showed that treatment with cadmium causes stimulation of the content on palmitic acid (C16: 0) followed by a fall in levels of linoleic acid (C18: 2) and linolenic (C18: 3) that suggests that cadmium causes alteration in de-saturation process of fatty acids ${ }^{[13]}$.
Finally, treatment with cadmium of Potato isolated mitochondria inhibits the activity of the Catalase enzyme reflecting a weak detoxification.

\section{CONCLUSION}

Following this study, it appears that cadmium generates in potato the isolated mitochondria a concentration-dependent oxidative stress. This is characterized by a malfunction of the alternative route for the transfer of electrons and an accumulation of peroxides and $\mathrm{H}_{2} \mathrm{O}_{2}$. As a direct consequence of inhibiting the activity of the antioxidant enzymes: The Catalase $^{[17]}$. Cadmium induces a swelling of mitochondria responsible for the release of Cytochrome $\mathrm{C}$ associated with the stimulation of transport of the potassium ion $\mathrm{K}^{+}$. The output of the $\mathrm{K}^{+}$ion accompanied by the decoupling of the mitochondrial respiratory chain inhibits the ATPase activity through alteration (discharge) of $\mathrm{H}^{+}$protons gradient $(\mathrm{pH}$ gradient). All these steps are the introductory phase of the apoptosis.

\section{REFERENCES}

1. Bomsel, J.L., 1973. Influence of energitic charge on the speed of saccharose synthesis in vivo. C. R. Acad. Sci., 277: 1753-1756.

2. Bradford, M.M., 1976. A rapid and sensitive method for the quantitation of microgram quantities of proteins utilizing the principle of protein-dye binding. Anal. Biochem., 72: 248-254. http://www.ncbi.nlm.nih.gov/pubmed/942051

3. Claes, W.H.S., 2008. Cadmium mediated changes in mitochondrial metabolic function of a renal epithelial cell line (A6), evaluated with the MTTassay. Master Project, Roskilde University (RUC). http://dspace.ruc.dk/bitstream/1800/3037/1/MTT.pdf

4. Delperée, C. and S. Lutts, 2008. Growth inhibition occurs independently of cell mortality in Tomato (Solanum lycopersicum) exposed to high cadmium concentrations. J. Int. Plant Biol., 3: 300-310. http://www.ncbi.nlm.nih.gov/pubmed/18713362

5. Djebar, M.R., 1988. Changing in membrane fluidity of mitochondria of potatoes through their energization: Effect of ethylene. C. R. Acad. Sci., 307: 741-744.

6. Djebar, M.R. and H. Djebar, 2000. Bioenergetics: The vegetal mitochondria. Rev. Sci. Technol. Ed. Veg., 8: 103-103.

7. Ducet, G., M.C. Martinon, P. Coulomb, M. Diano and D. Meunter, 1970. Tubercles of Potatos mitochondria. Physiol. Veg., 8: 35-54. 
8. Gallenco, S.M., M.P. Benavides and M.L. Tomaro, 1996. Effect of heavy metal ion excess on sunflower leaves: Evidence for involvement of oxidative stress. Plant Sci., 121: 151-159. http://cat.inist.fr $/$ aModele $=$ afficheN\&cpsidt $=2568397$

9. Habeebu, S.S.M., J. Liu and C.D. Klaassen, 1998. Cadmium-induced apoptosis in mouse liver. Toxicol. Applied Pharmacol., 149: 203-209. http://www.ncbi.nlm.nih.gov/pubmed/9571989

10. Ishido, M., H.S. Takeda, C. Tohyama and T. Suzuki, 1998. Apoptosis in rat renal proximal tubular cells induced by cadmium. J. Toxicol. Environ. Health, 55: $1-12$.

http://cat.inist.fr/?aModele $=$ afficheN\&cpsidt $=2392293$

11. Jimenez, A., J.A. Hernandez, L.A. Delrio and F. Sevilla, 1997. Evidence of the presence of the ascorbateglutatione cycle in mitochondria and peroxisomes of pea leaves. Plant Physiol., 114: 275-284. http://www.pubmedcentral.nih.gov/articlerender.fc gi? artid $=158303$

12. Masuo, K., O. Satoko, A. Saeko, H. Minoru and S. Masao, 2001. Cytochrome C release from mitochondria induced by cadmium. J. Health Sci., 471: 78-82. http://sciencelinks.jp/jeast/article/200110/000020011001A0234192.php

13. Ouariti, O., N. Boussama, M. Zarrouk, A. Cherif and M.H. Ghorbali, 1997. Cadmium and copper induced changes in tomato membranes lipids. Phytochemistry, 45: 1343-1350. http://www.ncbi.nlm.nih.gov/pubmed/9237398

14. Pradet, A., 1967. Study of adenosins 3-mono, diand triphosphates in vegetabl tissu. I: Enzymatic Dosage. Physiol. Veg., 5: 209-221.

15. Rasheed, A.B.K., J.J. Diwan and D.R. Sanadi, 2005. Activation of potassium transport in mitochondria by cadmium ion. Eur. J. Biochem., 144: 643-647.

16. Réinhectel, T., H. Noack, S. Lorenz, I. Wiswedel and W. Augustin, 1998. Comparison of protein oxidation and aldehyde formation during oxidative stress in isolated mitochondria. Free Radic. Res., 29: 297-305. http://www.ncbi.nlm.nih.gov/pubmed/9860044

17. Romero-Puertas, M.C., I. McCarty, I.M. Sandalio, J.M. Palma, F.J. Corpas, M. Gomez and L.A. Delrio, 1999. Cadmium toxicity and oxidative metabolism of pea leaf peroxisomes. Free Radic. Res., 1: 25-32. http://www.ncbi.nlm.nih.gov/pubmed/10694037
18. Romero-Puertas, M.C., F.J. Corpas, M.R. Serano, M. Gomez, L.A. Delrio and L.M. Sandalio, 2007. Differential expression and regulation of antioxidative enzymes by cadmium in pea plants. J. Plant Physiol., 164: 1348-1357. http://cat.inist.fr/?aModele $=$ afficheN\&cpsidt $=19135900$

19. Sandalio, L.M., H.C. Dalurzo, M. Gomez, M.C.R. Puertas and L.A. Delrio, 2001. Cadmiuminduced changes in the growth and oxidative metabolism of pea plants. J. Exp. Bot., 52: 2115-2126. http://www.ncbi.nlm.nih.gov/pubmed/11604450

20. Sbartai, H., R. Rouabhi, I. Sbartai, H. Berrebbah and M.R. Djebar, 2008. Induction of anti-oxidative enzymes by cadmium stress in tomato (Lycopersicum esculentum). Afr. J. Plant Sci., 2: $72-76$.

http://academicjournals.org/AJPS/PDF/Pdf2008/A ug/Sbartai\%20et\%20al.pdf

21. Shaw, B.P., 1995. Effects of mercury and cadmium on the activities of antioxidative enzyme in the seedlings of phaseolus aureus. Biol. Plant., 37: 587-596. DOI: 10.1007/BF02908843

22. Somashekaraiah, B.V., K. Padmaja and A.R.K. Prasad, 1992. Phytotoxicity of cadmium on germinating seedlings of mung bean (Phaseolus vulgaris)involvement of lipid peroxides in chlorophyll degradation. Physiol. Plant., 85: 85-89. DOI: 10.1111/j.1399-3054.1992.tb05267.x

23. Stohs, S.J. and D. Bagchi, 1995. Oxidative mechanisms in the toxicity of metal ions. Free Radic. Biol. Med., 18: 321-336. http://www.ncbi.nlm.nih.gov/pubmed/7744317

24. Tsangaris, G.T. and F.T. Stathopoulou, 1998. Cadmium induces apoptosis differentially on immune system cell lines. Toxicology, 128: 143-150. http://www.ncbi.nlm.nih.gov/pubmed/9710155

25. Van Ginkel, G. and J.S. Brown, 1978. Endogenous catalase and superoxide dismutase activities in photosynthetic membranes. FEBS. Lett., 94: 285-286.

26. Wagner, G.J., 1993. Accumulation of cadmium in crop plants and its consequences to human health. Adv. Agron., 51: 173-212. http://grande.nal.usda.gov/ibids/index.php?mode2= detail\&origin=ibids_references\&therow $=438844$ 